\title{
IN-MIGRATION AND CHANGING SOUTHERN POLITICAL ORIENTATIONS
}

\author{
Robert H. Freymeyer*
}

The South ${ }^{1}$ has attracted more than four million in-migrants in the last ten years. This influx of migrants threatens the South's traditional political distinctiveness. The solid Democratic South has witnessed the Republican Party's resurgence in recent elections-a resurgence related to the flow of in-migrants. This research examines Southern Republican development as well as other political consequences of the migration stream into the South. It expands on previous work documenting the Republican preferences of in-migrants as compared to native Southerners (e.g., Beck, 1977; Campbell et al., 1960; Gatlin, 1975; Knoke, 1976; Wolfinger and Arseneau, 1978) by documenting differences between migrants' and natives' views on important Southern political issues and differences between migrants and natives within each party. Migrant-native differences on these Southern political issues may suggest future changes in Southern political orientations.

Two aspects of Southern politics are considered: political party affiliation and political ideologies. Party identification is remarkably constant and is an important, if not the most important, aspect of Southern voting decisions (Beck, 1977; Gatlin, 1975; Miller and Levitin, 1976; Wolfinger and Arseneau, 1978). Inmigrants and native Southerners are grouped according to whether they consider themselves to be Democrats, Republicans, or Independents. Those Independents who think of themselves as closer to one of the parties are classified as members of that party. This strategy may mask

\footnotetext{
*This research was conducted as part of a National Endowment for the Humanities supported Summer Seminar at the University of North Carolina, Chapel Hill. The author gratefully acknowledges the assistance of John Shelton Reed, Seminar Director. The author also has benefited from discussions of this research with P. Neal Ritchey and James L. Guth. This paper is based on an earlier version presented at the Annual Meeting of the Population Association of America, Washington, D.C., March 1981.
}

some of the ideological differences found between "true" partisans. The "leaning" Independents are not as strongly committed to the parties; yet, the partisan Independents are likely to vote with the party toward which they are leaning (Wolfinger and Arseneau, 1978). Classifying them as members of a party provides a conservative indication of the differences between the parties.

Political ideologies differ between the two major political parties. These differences are recognized by the public (Kessel, 1972; Pomper, 1972). To determine the issues underlying Southern political parties' ideologies, the views of Southern Republicans and Southern Democrats are compared on a number of issues traditionally important in Southern politics. Race has been the dominant Southern political issue (Bass and DeVries, 1976; Key, 1949). Although its role may be changing because of the Voting Rights Act and because of migration (Beck, 1977; Black, 1978; Wolfinger and Arseneau, 1978), it is an obvious issue to consider in an examination of Republican and Democratic differences. Other issues that have been traditionally important in the South include economics, including the debate between those with business and labor orientations (Black et al., 1974; Pomper, 1972); welfare policy (Cebula, 1979); crime (Black et al., 1974); defense/foreign aid (Nie and Anderson, 1974); and states' rights (Kessel, 1972). Furthermore, Southerners have had unique views concerning several major institutions (Reed, 1972): organized religion, education, the scientific community and the press. The goal of this analysis is to select empirically the most discriminating issues today.

Data for this study are taken from the General Social Survey (GSS) conducted periodically by the National Opinion Research Center (NORC) (Davis, 1978). The NORC administers a series of identical questions to national sam- 
ples of English-speaking, non-institutionalized adults living in the United States. The responses for 1976, 1977, and 1978 are used in this analysis. This study's sample is limited to those who lived in the South at the time of the NORC interview $(N=1491)$.

Questions measuring views on political issues are taken from the GSS. A complete listing of the GSS questions used is provided in Appendix I. Migrant status is measured using the GSS question "In what state or foreign country were you living when you were 16 years old?" Those reporting living in the South at the age of sixteen are classified as native Southerners while those living outside the South at the age of sixteen are in-migrants. ${ }^{2}$

In addition to considering differences between in-migrants and natives, comparisons are made between migrant Republicans, migrant Decmorats, native Republicans, and native Democrats to examine the impact of party affiliation and migrant status. The examination assumes that Republicans and Democrats from the non-South may differ from the Southerners in each respective party. In this manner a more complete understanding of migration's influence on Southern politics is gained.

Political Party Affiliation. The results reported in Table 1, similar to previous findings (Beck, 1977; Campbell et al., 1960; Gatlin, 1975; Wolfinger and Arseneau, 1978), suggest that migrants to the South are more likely to consider themselves to be Republicans (36.5 percent) than are native Southerners (26.7 percent). Migrants, furthermore, more often report that they are unaligned Independents (19.8 percent) than do natives (13.6 percent). Before

TABLE 1.

Political Party Affiliation by Migrant Statusa

\begin{tabular}{lcc}
\hline Political Party & $\begin{array}{c}\text { Native } \\
\text { Southerners }\end{array}$ & $\begin{array}{c}\text { Migrant } \\
\text { Southerners }\end{array}$ \\
\hline Democrats & $59.6 \%$ & $43.2 \%$ \\
& $(56.1 \%)$ & $(42.1 \%)$ \\
Independents & $13.6 \%$ & $19.8 \%$ \\
& $(13.9 \%)$ & $(19.3 \%)$ \\
Republicans & $26.7 \%$ & $36.5 \%$ \\
& $(30.1 \%)$ & $(38.6 \%)$ \\
Others & $.2 \%$ & $.4 \%$ \\
$\mathrm{~N}=$ & 1258 & 227 \\
& $(1024)$ & $(207)$ \\
\hline
\end{tabular}

aResults for whites only are in parentheses. they moved, at least some of the Independents could have been Republicans who found no organized Republican Party in the area to which they moved or who found a Party whose members had viewpoints that were perceived to be different from their own viewpoint. Thus, they became Independents by default. Migrants also are less likely to consider themselves as Democrats (43.2 percent) as compared with natives (59.6 percent Democrats). Among the migrants, the Democratic Party is still the strongest party, but it does not enjoy the strength that it enjoys among natives. ${ }^{3}$ The migrants have contributed not only to the rise of the Republican Party in the South, but also to Southern dealignment. They have been a part of the increase in the number of Independents in the region. ${ }^{4}$

Party Identification and Issue Relevance in the South. In-migrants to the South provide a support base for the development of the region's Republican Party, and, more generally, for the decline of the solidly Democratic South. After an assimilation period, these "transplanted Northerners are more likely to vote than the natives" (Wolfinger and Rosenstone, 1980:94; similar findings for other migrants' political participation rates have been noted by Freedman and Freedman, 1956; Jitodai, 1964; Rieger and Beegle, 1974; Sharp, 1955; Zimmer, 1955). The next question of concern is whether these migrants' views on important Southern political issues are similar to those of natives. An indication of Southern political ideologies today is obtained by comparing the political views characteristic of Southern Republicans with those characteristic of Southern Democrats. While the Independents' views are important, the focus is on political parties. The technique used for this comparison is discriminant analysis. This design selects a set of variables (issues) which distinguish between members of the political parties. A linear combination of these variables forms the discriminant function separating the two groups. Issues making a significant contribution to the discriminant function, those on which Republicans and Democrats have different opinions, are considered the principle Southern political issues. Standardized discriminant function coefficients, which are analogous to betas in multiple regression, also are calculated, indicating the relative contribution of each issue in the function (Nie et al., 1975). 
The discriminant function is able to classify correctly members of each party in 61.4 percent of the cases. Table 2 lists the issues making a significant contribution to the discriminant function. The question concerning expenditures for improving the conditions of blacks is not a significant discriminating variable nor is the question concerning expenditures for welfare. The former question most obviously examines the views concerning treatment of blacks; yet views on this question are not different for Southern members of each major political party. Race per se is not as important today in Southern politics as it once was, although racerelated issues, e.g., busing (BUSING- $d=$ .337) and spending to protect the nation's health (NATHEAL- $\mathrm{d}=.423),{ }^{5}$ still have some importance. Carmines and Stimson (1980) argued that racial desgregation in general is an "easy issue" as perhaps is improving the conditions of blacks. As easy issues, opinions about them "should be distributed reasonably evenly

TABLE 2.

Results of Discriminant Analysis Distinguishing Between Southern Democrats and Southern Republicans

\begin{tabular}{|c|c|c|}
\hline \multicolumn{3}{|c|}{ Classification Results } \\
\hline \multirow[t]{2}{*}{ Actual Group } & \multicolumn{2}{|c|}{ Predicted Group } \\
\hline & Democrats & Republicans \\
\hline $\begin{array}{l}\text { Democrats } \\
(\mathrm{N}=586)\end{array}$ & $61.1 \%$ & $38.9 \%$ \\
\hline $\begin{array}{l}\text { Republicans } \\
(\mathrm{N}=273)\end{array}$ & $38.1 \%$ & $61.9 \%$ \\
\hline $\begin{array}{l}\text { Percent of "Grouped' } \\
61.4 \%\end{array}$ & Cases Correc & y Classified = \\
\hline \multicolumn{3}{|c|}{ Standardized Discriminant Function Coefficients } \\
\hline Variable $^{a}$ & \multicolumn{2}{|c|}{ Coefficient } \\
\hline CONLEGIS & \multicolumn{2}{|c|}{.465} \\
\hline NATHEAL & \multicolumn{2}{|c|}{.423} \\
\hline CONEDUC & \multicolumn{2}{|c|}{.342} \\
\hline BUSING & \multicolumn{2}{|c|}{.337} \\
\hline CONJUDGE & \multicolumn{2}{|c|}{-.335} \\
\hline COMPRESS & \multicolumn{2}{|c|}{.232} \\
\hline NATCITY & \multicolumn{2}{|c|}{.230} \\
\hline NATSPAC & \multicolumn{2}{|c|}{-.209} \\
\hline CONLABOR & \multicolumn{2}{|c|}{.204} \\
\hline CONARMY & \multicolumn{2}{|c|}{-.178} \\
\hline NATAID & \multicolumn{2}{|c|}{-.154} \\
\hline $\begin{array}{r}\text { ABDEFECT } \\
\mathrm{X}^{2}=55\end{array}$ & \multicolumn{2}{|c|}{$18 ; p<.001$} \\
\hline
\end{tabular}

aSee Appendix I for variable description. in the voting population" (78). Busing and, particularly, spending to protect the nation's health are "hard-issues" for which voters are likely to have differing opinions.

Other issues making substantial contributions to the discriminant function include views concerning confidence in Congress (CONLEGIS- $d=.465)$ and the Supreme Court (CONJUDGE- $d=-.335$ ), possibly indicating the importance of states' rights in Southern politics. Views concerning confidence in education $(\mathrm{CONEDUC}-\mathrm{d}=.342)$ and the press $(\mathrm{CON}$ PRESS $-\mathrm{d}=.232$ ) also discriminate between Republicans and Democrats. Furthermore, several economic issues are significant: spending to solve the problems of big cities (NATCITY$\mathrm{d}=.230$ ), spending for space exploration (NATSPACE- $d=-.209$ ), and spending for foreign aid (NATAID-d $=-.154$ ). The national Republican and Democratic parties have long differed on economic issues. These differences are found for the South as well. Further discussion of each issue is presented in the examination of the migrant-native political party differences.

Differences in migrants' and natives' views on these issues which shape Southern parties' ideologies would suggest a substantial migrant impact on the course of Southern politics. These differences are examined in the next section.

Migration Status and Issue Relevance in the South. The issues distinguishing between the views of Southern Republicans and Southern Democrats discriminate between native Southerners and in-migrants with about the same efficiency as they discriminate between the members of the parties, i.e., 60 percent of the cases are correctly classified, as the results in Table 3 indicate.

The issue which most distinguishes the two groups is the confidence each group has in the educational institution (CONEDUC- $d=$ $-.624)$. Other important views are those concerning abortion (ABDEFECT- $\mathrm{d}=.481$ ), confidence in labor unions (CONLABOR- $d=$ -.473 ), and confidence in the Supreme Court (CONJUDGE-d $=.437$ ).

Examining the issues that are significant discriminators, along with previous findings, begins to provide an indication of the possible impact of migrants. Migrants are a somewhat distinctive group. In particular, they view several major institutions differently from natives. These institutions' structures, or in the case of 
TABLE 3.

Results of Discriminant Analysis Distinguishing Between Migrants to the South and Southern Natives

Classification Results

\begin{tabular}{lcc}
\hline \multirow{2}{*}{ Actual Group } & \multicolumn{2}{c}{ Predicted Group } \\
\cline { 2 - 3 } & Natives & Migrants \\
\hline Natives & $59.3 \%$ & $40.7 \%$ \\
$(\mathrm{~N}=995)$ & $37.2 \%$ & $62.8 \%$ \\
Migrants & \\
(N = 183) & \\
Percent of “Grouped" Cases Correctly \\
Classified = 60.0\% & \\
\hline Standardized Discriminant Function Coefficients \\
\hline \multicolumn{1}{c}{ Variable } & Coefficient \\
\hline CONEDUC & -.624 \\
ABDEFECT & .481 \\
CONLABOR & -.473 \\
CONJUDGE & .437 \\
BUSING & .254 \\
NATSPAC & .204 \\
& $\mathrm{x}^{2}=27.70 ; \mathrm{p}<.001$ \\
\hline
\end{tabular}

asee Appendix I for variable description.

labor unions the lack of the institution, contribute to Southern distinctiveness. Migrants have a role in Southern politics and an influence on the direction of future political decisions and future Southern developments. Yet, several issues which discriminate between Southern Republicans and Democrats do not discriminate between natives and migrants. The next section examines these issues which indicate intraparty differences between natives and migrants.

Migration, Party Affiliation, and Issue Relevance in the South. Southern Republicans and Democrats have different views on several issues. The differences in the views of native Republicans, migrant Republicans, native Democrats, and migrant Democrats on these discriminating issues are compared now. The results of the discriminant analysis for this four group comparison are presented in Table 4. (Only the two statistically significant functions are reported.) The discriminant functions correctly classify 33.8 percent of the cases. The functions best predict the group membership of migrant Republicans (56.3 percent correct) and migrant Democrats (40.0 percent). These two groups are most distinct.

The group centroids, which are "the mean discriminant scores for each group on the respective functions," (Nie et al., 1975:440) are useful for determining the dimension on which each function is discriminating. The biggest distinction for function one is between migrant Republicans and all other groups. The centroid for migrant Republicans is farther away from the next closest centroid for native Republicans, than the native Republican centroid is from the opposite extreme centroid for native Democrats. Migrant Republicans differ in important ways from native Republicans, as well as all other groups, on the variables contributing to function one-a uniqueness which is noted in many of the other findings as well. For the second function, the centroids suggest that the migrant-native dimension is the most important one. The centroids for migrant Democrats (.355) and migrant Republicans (.171) are on the opposite extreme from the centroids for natives in each party.

Views on several issues discriminate among migrant Republicans, native Republicans, migrant Democrats, and native Democrats. These issues are confidence in the Supreme Court, Congress, education, and labor unions; expenditures for the nation's health, space exploration, and foreign aid; and views concerning busing and abortion. These significant discriminating variables are examined further through the crosstabulation of each issue by each group. In addition to the analysis conducted on the total sample, a separate analysis is performed for whites only. Most migrant Republicans are white while the Southern Democratic Party contains a substantial number of blacks. This additional analysis for whites removes the competing effects of race from the results. Crosstabulations are presented in Tables 5-10 for those issues for which there is a significant difference between the groups' views.

Racial issues have dominated Southern politics for most of the region's history (e.g., Key, 1949). The four groups' views differ on the racerelated issue of busing. The results presented in Table 5 indicate that Democrats are more likely to favor busing, although the majority of both parties are opposed to busing. Additionally, the migrants of both parties are slightly more liberal on this issue. White native Southerners are more opposed to busing than is the total sample which includes blacks. The difference for native Democrats is particularly noteworthy since this group contains the largest percentage of blacks. 
TABLE 4.

Results of Discriminant Analysis Distinguishing Between Native Democrats, Migrant Democrats, Native Republicans, and Migrant Republicans

\begin{tabular}{|c|c|c|c|c|}
\hline \multicolumn{5}{|c|}{ Classification Results } \\
\hline \multirow[t]{2}{*}{ Actual Group } & \multicolumn{4}{|c|}{ Predicted Group } \\
\hline & $\begin{array}{c}\text { Native } \\
\text { Democrats }\end{array}$ & $\begin{array}{c}\text { Migrant } \\
\text { Democrats }\end{array}$ & $\begin{array}{c}\text { Native } \\
\text { Republicans }\end{array}$ & $\begin{array}{c}\text { Migrant } \\
\text { Republicans }\end{array}$ \\
\hline $\begin{array}{l}\text { Native } \\
\text { Democrats } \\
(\mathrm{N}=578)\end{array}$ & $34.4 \%$ & $27.0 \%$ & $20.2 \%$ & $18.3 \%$ \\
\hline $\begin{array}{l}\text { Migrant } \\
\text { Democrats } \\
(\mathrm{N}=\mathbf{8 0})\end{array}$ & $22.5 \%$ & $40.0 \%$ & $15.0 \%$ & $22.5 \%$ \\
\hline $\begin{array}{l}\text { Native } \\
\text { Republicans } \\
(\mathrm{N}=244)\end{array}$ & $26.2 \%$ & $20.1 \%$ & $23.8 \%$ & $29.9 \%$ \\
\hline $\begin{array}{l}\text { Migrant } \\
\text { Republicans } \\
(\mathrm{N}=71)\end{array}$ & $8.5 \%$ & $18.3 \%$ & $16.9 \%$ & $56.3 \%$ \\
\hline \multicolumn{5}{|c|}{ Percent of "Grouped" Cases Correctly Classified $=33.8 \%$} \\
\hline \multicolumn{5}{|c|}{ Group Centroids } \\
\hline Group & Function 1 & & Function 2 & \\
\hline Migrant Republicans & -.859 & & .171 & \\
\hline Native Republicans & -.258 & & -.163 & \\
\hline Migrant Democrats & .064 & & .355 & \\
\hline Native Democrats & .205 & & -.008 & \\
\hline \multicolumn{5}{|c|}{ Standardized Discriminant Function Coefficients } \\
\hline Variable $^{a}$ & & $\begin{array}{l}\text { Function } 1 \\
\text { Coefficients }\end{array}$ & & $\begin{array}{l}\text { Function } 2 \\
\text { Coefficients } \\
\end{array}$ \\
\hline CONJUDGE & & .504 & & -.199 \\
\hline NATHEAL & & -.471 & & -.328 \\
\hline CONLEGIS & & -.443 & & -.239 \\
\hline CONEDUC & & -.394 & & .505 \\
\hline CONLABOR & & -.389 & & .190 \\
\hline BUSING & & -.259 & & -.608 \\
\hline NATSPAC & & .212 & & -.124 \\
\hline NATAID & & .204 & & .158 \\
\hline ABDEFECT & & $\begin{array}{c}.058 \\
=98.70 ; p<.001\end{array}$ & & $\begin{array}{c}-.525 \\
\mathrm{x}^{2}=19.28 ; \mathrm{p}=.25\end{array}$ \\
\hline
\end{tabular}

aSee Appendix I for variable' description.

Only 9.3 percent of the white native Democrats support busing while the percentage of all native Democrats supporting it is $\mathbf{2 0 . 3}$ percent, suggesting that blacks in this group are more strongly in favor. The stereotype of the white racially conservative Southerner is supported. The Republican Party also is found to be more prejudiced against civil rights.

A similar distribution, reported in Table 6, is found for views concerning expenditures for improving and protecting the nation's health, another issue with racial implications. There is not, however, the difference between whites and the total sample noted in the findings for busing views. Democrats are more likely to feel that too little is being spent on the nation's health, and, as with busing, the migrants are slightly more likely than the natives to take this liberal position. Although migrant Republicans are more likely to feel that too little is 
TABLE 5.

Views Toward Busing for Native Democrats, Migrant Democrats, Native Republicans, and Migrant Republicans ${ }^{a}$

\begin{tabular}{|c|c|c|}
\hline Political Party & Favor & Oppose \\
\hline $\begin{array}{l}\text { Native Democrats } \\
N=735 \\
(\mathrm{~N}=562)\end{array}$ & $\begin{array}{l}20.3 \% \\
(9.3 \%)\end{array}$ & $\begin{array}{c}79.7 \% \\
(90.7 \%)\end{array}$ \\
\hline $\begin{array}{l}\text { Migrant Democrats } \\
N=94 \\
(N=84)\end{array}$ & $\begin{array}{c}21.3 \% \\
(17.9 \%)\end{array}$ & $\begin{array}{c}78.7 \% \\
(82.1 \%)\end{array}$ \\
\hline $\begin{array}{l}\text { Native Republicans } \\
N=326 \\
(\mathrm{~N}=297)\end{array}$ & $\begin{array}{c}9.8 \% \\
(6.1 \%)\end{array}$ & $\begin{array}{c}90.2 \% \\
(93.9 \%)\end{array}$ \\
\hline \multirow{2}{*}{$\begin{array}{l}\text { Migrant Republicans } \\
N=80 \\
(N=77)\end{array}$} & $\begin{array}{c}13.8 \% \\
(13.0 \%)\end{array}$ & $\begin{array}{c}86.3 \% \\
(87.0 \%)\end{array}$ \\
\hline & \multicolumn{2}{|c|}{$\begin{array}{r}x^{2}=19.15 ; p<.001 \\
\left(x^{2}=12.20 ; p<.05\right)\end{array}$} \\
\hline
\end{tabular}

'Results for whites only are in parentheses.

being spent (50.6 percent for migrants, 47.8 percent for natives), there is a substantial percentage of migrants (17.7) who feel that too much is being spent. Among migrant Republicans there is a fiscally-conservative core.

The other issue concerned with expenditures on which the four groups differ significantly is spending for space exploration. On this issue Democrats are more likely to feel that too much is being spent. As the results presented in Table 7 document, Democrats who in general are more willing to spend for social programs such

TABLE 6.

Views Toward Expenditures for Protecting the Nation's Health for Native Democrats, Migrant Democrats, Native Republicans, and Migrant Republicans ${ }^{\mathrm{a}}$

\begin{tabular}{|c|c|c|c|}
\hline Political Party & $\begin{array}{l}\text { Too } \\
\text { Little }\end{array}$ & $\begin{array}{l}\text { About } \\
\text { Right }\end{array}$ & $\begin{array}{l}\text { Too } \\
\text { Much }\end{array}$ \\
\hline $\begin{array}{l}\text { Native Democrats } \\
N=716 \\
(N=544)\end{array}$ & $\begin{array}{c}61.3 \% \\
(58.4 \%)\end{array}$ & $\begin{array}{c}34.8 \% \\
(37.3 \%)\end{array}$ & $\begin{array}{c}3.9 \% \\
(4.2 \%)\end{array}$ \\
\hline $\begin{array}{l}\text { Migrant Democrats } \\
N=91 \\
(N=80)\end{array}$ & $\begin{array}{c}64.8 \% \\
(61.2 \%)\end{array}$ & $\begin{array}{c}30.8 \% \\
(35.0 \%)\end{array}$ & $\begin{array}{c}4.4 \% \\
(3.8 \%)\end{array}$ \\
\hline $\begin{array}{l}\text { Native Republicans } \\
N=314 \\
(\mathbf{N}=287)\end{array}$ & $\begin{array}{c}47.8 \% \\
(48.4 \%)\end{array}$ & $\begin{array}{c}43.9 \% \\
(43.6 \%)\end{array}$ & $\begin{array}{l}8.3 \% \\
(8.0 \%)\end{array}$ \\
\hline \multirow{2}{*}{$\begin{array}{l}\text { Migrant Republicans } \\
\mathbf{N}=79 \\
(\mathbf{N}=77)\end{array}$} & $\begin{array}{c}50.6 \% \\
(49.4 \%)\end{array}$ & $\begin{array}{c}31.6 \% \\
(32.5 \%)\end{array}$ & $\begin{array}{c}17.7 \% \\
(18.2 \%)\end{array}$ \\
\hline & \multicolumn{3}{|c|}{$\begin{aligned} x^{2} & =41.55 ; p<.001 \\
\left(x^{2}\right. & =30.35 ; p<.001)\end{aligned}$} \\
\hline
\end{tabular}

aResults for whites only are in parentheses. as national health care are less willing to spend for technologically-oriented programs. Migrant Republicans again take an extreme position: they are more likely to express the view that too little is being spent on space exploration (19.8 percent versus 10.4 percent for migrant Democrats, the closest group). In contrast to the migrant Republican core group opposed to spending for health care, there is a core of support for economic development in terms of spending for space exploration. This migrant group, who may not be the same in both cases, supports an economic program that benefits business and opposes one benefiting social welfare. These policies are traditional Republican ones.

Migrant Republicans have less confidence in the educational institution in this country (only 20.5 percent have a great deal of confidence), as shown in the results presented in Table 8 . Native Democrats have the most confidence in this institution (46.9 percent have a great deal of confidence). Southerners maintain higher levels of confidence in education in spite of the facts that Southern schools are of lower quality than schools of other regions and Southern states spend less on education than other states. Migrants have been exposed to schools in at least two regions of the country. Their lack of confidence in education could reflect their first-hand knowledge of the relative quality of Southern schools as compared to other schools. Another possible explanation involves the

TABLE 7.

\begin{tabular}{|c|c|c|c|}
\hline \multicolumn{4}{|c|}{$\begin{array}{l}\text { Views Toward Expenditures for Space Exploration for } \\
\text { Native Democrats, Migrant Democrats, Native } \\
\text { Republicans, and Migrant Republicans }\end{array}$} \\
\hline Political Party & $\begin{array}{l}\text { Too } \\
\text { Little }\end{array}$ & $\begin{array}{l}\text { About } \\
\text { Right }\end{array}$ & $\begin{array}{l}\text { Too } \\
\text { Much }\end{array}$ \\
\hline $\begin{array}{l}\text { Native Democrats } \\
N=711 \\
(\mathrm{~N}=541)\end{array}$ & $\begin{array}{c}9.3 \% \\
(11.1 \%)\end{array}$ & $\begin{array}{l}30.7 \% \\
(32.7 \%)\end{array}$ & $\begin{array}{l}60.1 \% \\
(56.2 \%)\end{array}$ \\
\hline $\begin{array}{l}\text { Migrant Democrats } \\
N=96 \\
(\mathrm{~N}=86)\end{array}$ & $\begin{array}{l}10.4 \% \\
(10.5 \%)\end{array}$ & $\begin{array}{l}31.3 \% \\
(33.7 \%)\end{array}$ & $\begin{array}{l}58.3 \% \\
(55.8 \%)\end{array}$ \\
\hline $\begin{array}{l}\text { Native Republicans } \\
N=316 \\
(\mathrm{~N}=288)\end{array}$ & $\begin{array}{l}7.3 \% \\
(8.0 \%)\end{array}$ & $\begin{array}{l}38.0 \% \\
(39.6 \%)\end{array}$ & $\begin{array}{l}54.7 \% \\
(52.4 \%)\end{array}$ \\
\hline \multirow{2}{*}{$\begin{array}{l}\text { Migrant Republicans } \\
N=81 \\
(\mathrm{~N}=79)\end{array}$} & $\begin{array}{l}19.8 \% \\
(20.2 \%)\end{array}$ & $\begin{array}{l}38.3 \% \\
(38.0 \%)\end{array}$ & $\begin{array}{c}42.0 \% \\
(41.8 \%)\end{array}$ \\
\hline & \multicolumn{3}{|c|}{$\begin{aligned} x^{2} & =19.60 ; p<.01 \\
\left(x^{2}\right. & =14.25 ; p<.05)\end{aligned}$} \\
\hline
\end{tabular}

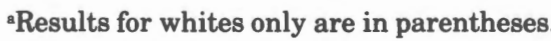


TABLE 8.

Confidence in Education for Native Democrats, Migrant Democrats, Native Republicans and Migrant Republicans ${ }^{a}$

\begin{tabular}{|c|c|c|c|}
\hline Political Party & $\begin{array}{l}\text { Great } \\
\text { Deal }\end{array}$ & $\begin{array}{l}\text { Only } \\
\text { Some }\end{array}$ & $\begin{array}{l}\text { Hardly } \\
\text { Any }\end{array}$ \\
\hline $\begin{array}{l}\text { Native Democrats } \\
N=737 \\
(N=541)\end{array}$ & $\begin{array}{c}46.9 \% \\
(44.9 \%)\end{array}$ & $\begin{array}{c}44.9 \% \\
(47.4 \%)\end{array}$ & $\begin{array}{l}8.1 \% \\
(7.6 \%)\end{array}$ \\
\hline $\begin{array}{l}\text { Migrant Democrats } \\
N=96 \\
(N=86)\end{array}$ & $\begin{array}{c}35.4 \% \\
(36.9 \%)\end{array}$ & $\begin{array}{c}51.0 \% \\
(48.8 \%)\end{array}$ & $\begin{array}{c}13.5 \% \\
(14.3 \%)\end{array}$ \\
\hline $\begin{array}{l}\text { Native Republicans } \\
N=327 \\
(\mathrm{~N}=288)\end{array}$ & $\begin{array}{l}38.5 \% \\
(37.3 \%)\end{array}$ & $\begin{array}{l}47.7 \% \\
(48.0 \%)\end{array}$ & $\begin{array}{c}13.8 \% \\
(14.7 \%)\end{array}$ \\
\hline \multirow{2}{*}{$\begin{array}{l}\text { Migrant Republicans } \\
N=83 \\
(N=79)\end{array}$} & $\begin{array}{l}20.5 \% \\
(21.2 \%)\end{array}$ & $\begin{array}{c}65.1 \% \\
(63.8 \%)\end{array}$ & $\begin{array}{c}14.5 \% \\
(15.0 \%)\end{array}$ \\
\hline & \multicolumn{3}{|c|}{$\begin{array}{c}x^{2}=31.37 ; p<.001 \\
\left(x^{2}=25.20 ; p<.001\right)\end{array}$} \\
\hline
\end{tabular}

aResults for whites only reported in parentheses.

quality of the Southern labor force. If Northerners find Southern laborers lacking abilities, they might assume that Southerners received poor schooling, thus decreasing their confidence in the educational institution.

Democrats, who controlled Congress during the survey period, are more likely to express a great deal of confidence in Congress, as reported in Table 9. For this issue the views of natives of both parties are similar, perhaps because they have benefited from the same federal programs which have aided the South, e.g.,

TABLE 9.

Confidence in Congress for Native Democrats, Migrant Democrats, Native Republicans, and Migrant Republicans $^{a}$

\begin{tabular}{|c|c|c|c|}
\hline Political Party & $\begin{array}{c}\text { Great } \\
\text { Deal }\end{array}$ & $\begin{array}{l}\text { Only } \\
\text { Some }\end{array}$ & $\begin{array}{c}\text { Hardly } \\
\text { Any }\end{array}$ \\
\hline $\begin{array}{l}\text { Native Democrats } \\
N=722 \\
(\mathrm{~N}=552)\end{array}$ & $\begin{array}{c}19.8 \% \\
(20.1 \%)\end{array}$ & $\begin{array}{c}62.3 \% \\
(61.4 \%)\end{array}$ & $\begin{array}{c}17.9 \% \\
(18.5 \%)\end{array}$ \\
\hline $\begin{array}{l}\text { Migrant Democrats } \\
\mathrm{N}=96 \\
(\mathrm{~N}=85)\end{array}$ & $\begin{array}{c}21.9 \% \\
(23.5 \%)\end{array}$ & $\begin{array}{c}67.7 \% \\
(64.7 \%)\end{array}$ & $\begin{array}{c}10.4 \% \\
(11.8 \%)\end{array}$ \\
\hline $\begin{array}{l}\text { Native Republicans } \\
N=317 \\
(\mathrm{~N}=293)\end{array}$ & $\begin{array}{c}17.7 \% \\
(16.4 \%)\end{array}$ & $\begin{array}{c}57.7 \% \\
(58.0 \%)\end{array}$ & $\begin{array}{l}24.6 \% \\
(25.6 \%)\end{array}$ \\
\hline \multirow{2}{*}{$\begin{array}{l}\text { Migrant Republicans } \\
N=83 \\
(\mathrm{~N}=80)\end{array}$} & $\begin{array}{c}7.2 \% \\
(7.5 \%)\end{array}$ & $\begin{array}{c}62.7 \% \\
(63.8 \%)\end{array}$ & $\begin{array}{c}30.1 \% \\
(28.8 \%)\end{array}$ \\
\hline & \multicolumn{3}{|c|}{$\begin{aligned} x^{2} & =22.22 ; p<.001 \\
\left(x^{2}\right. & =19.10 ; p<.01)\end{aligned}$} \\
\hline
\end{tabular}

aResults for whites only reported in parentheses. military installations, and have suffered from the same programs which often have been perceived as harming the South or infringing on the rights of the Southern states, e.g., the Voting Rights Act. In contrast, the views of migrants of both parties are more extreme than the views of the native members of their respective party. Migrant Democrats have the most confidence in Congress (21.9 percent express a great deal of confidence), whereas migrant Republicans have the least confidence (30.1 percent express hardly any confidence). Again, there is a core group of migrant Republicans who are distinctive. The findings for whites continue to be similar to the overall findings.

The South has been the most anti-union region in the country; North Carolina, for example, is the least unionized state in the country and most other Southern states are not far behind. All Southern states have "right-towork" laws (Biggar, 1979). But, the results presented in Table 10 suggest that migrant Republicans have the least confidence in labor unions (58.0 percent express hardly any confidence). It is likely that many of these migrant Republicans are business executives attracted to the South because of its lack of union activity. Their lack of confidence in labor unions probably reflects their occupational position. Native Democrats express the most confidence in this institution although only 18.2 percent express a great deal of confidence. Although the region as a whole has tended to be against unions,

\section{TABLE 10.}

Confidence in Organized Labor for Native Democrats, Migrant Democrats, Native Republicans, and Migrant Republicans $^{\mathrm{a}}$

\begin{tabular}{|c|c|c|c|}
\hline Political Party & $\begin{array}{c}\text { Great } \\
\text { Deal }\end{array}$ & $\begin{array}{l}\text { Only } \\
\text { Some }\end{array}$ & $\begin{array}{c}\text { Hardly } \\
\text { Any }\end{array}$ \\
\hline $\begin{array}{l}\text { Native Democrats } \\
N=686 \\
(\mathrm{~N}=529)\end{array}$ & $\begin{array}{c}18.2 \% \\
(17.0 \%)\end{array}$ & $\begin{array}{c}50.6 \% \\
(49.1 \%)\end{array}$ & $\begin{array}{c}31.2 \% \\
(33.9 \%)\end{array}$ \\
\hline $\begin{array}{l}\text { Migrant Democrats } \\
N=91 \\
(N=79)\end{array}$ & $\begin{array}{c}13.2 \% \\
(15.2 \%)\end{array}$ & $\begin{array}{c}54.9 \% \\
(51.9 \%)\end{array}$ & $\begin{array}{c}31.9 \% \\
(32.9 \%)\end{array}$ \\
\hline $\begin{array}{l}\text { Native Republicans } \\
N=302 \\
(\mathrm{~N}=276)\end{array}$ & $\begin{array}{c}13.9 \% \\
(13.4 \%)\end{array}$ & $\begin{array}{c}42.1 \% \\
(40.9 \%)\end{array}$ & $\begin{array}{c}44.0 \% \\
(45.7 \%)\end{array}$ \\
\hline \multirow{2}{*}{$\begin{array}{l}\text { Migrant Republicans } \\
N=81 \\
(N=78)\end{array}$} & $\begin{array}{l}2.5 \% \\
(2.6 \%)\end{array}$ & $\begin{array}{c}39.5 \% \\
(39.7 \%)\end{array}$ & $\begin{array}{c}\mathbf{5 8 . 0 \%} \\
(\mathbf{5 7 . 7 \% )}\end{array}$ \\
\hline & \multicolumn{3}{|c|}{$\begin{array}{c}x^{2}=39.01 ; p<.001 \\
\left(x^{2}=27.96 ; p<.001\right)\end{array}$} \\
\hline
\end{tabular}

aResults for whites only reported in parentheses. 
there is some union activity, for example, in the steel industry in Alabama.

\section{Conclusions}

Accompanying the recent rapid Southern growth, and partially resulting from it, has been a break in the solidly Democratic South. The "new" Southerners are more likely to consider themselves to be Republicans or Independents than are natives. Their views are different from natives as well as from each other. Of particular interest for this work, are the differences between the migrant Republicans and both the natives and the other migrants. These migrant Republicans stand out from the others. They are more moderate than native Republicans on race-related isues such as busing and expenditures to insure the nation's health, although they are not as liberal as Democrats. Also, they are more likely than any other group to think too little is being spent on space exploration. Finally, these migrant Republicans have less confidence in several institutions in American society: Congress, education, and labor unions. These differences between the parties are found in spite of the fact that individuals who consider themselves as Independents but leaning toward one of the parties are classified as members of the party. This classification probably reduces the overall differences between the "hard-core" partisans. Comparisons of just the Republicans and Democrats would produce even more extreme differences.

Many of the migrants to the South are better educated and engaged in higher status occupations than are natives (Biggar, 1979; Strong, 1977). They are a part, as well as a cause, of the development of the South from a primarily rural, agricultural area to an industrializing, urbanizing area, "infus(ing) the Southern cities with northern executives and technicians, many of them Republicans" (Sundquist, 1973:258). It is not surprising that these Republicans are in favor of increasing research and development expenditures, for example, in the space program. Nor is it unusual that they are less supportive of new government expenditures to improve the nation's health. Migrant Republicans' economic views are consistent with those of the national party to which they owe allegiance. Their lack of confidence in labor unions also is consistent with the Republican Party's business orientation.
Migrants who themselves are better educated express less confidence in schools. They realize the importance of quality education and are aware of the decline which has occurred in the nation's schools. To obtain the quality work force needed by industries moving South, good schools are necessary. Southern states are improving the quality of their schools as inducement to industry and, therefore, to Southern economic development. South Carolina, for example, built technical schools to train laborers for industries moving into the state.

Another institution in which migrant Republicans have less confidence than the other groups studied is Congress. Representatives in Congress from the South in the past mostly have been Democrats. The Republicans did not even compete seriously in many of these elections. During the elections of 1952, 1954, and 1956 , Republicans ran candidates in only about half of the 22 Southern Senate races and about one-third of the House races (Wolfinger and Arseneau, 1978:183). The Solid South began changing in the 1964 Presidential election when Barry Goldwater appealed to Southern racial sentiments as a means of attracting support (Bass and DeVries, 1976). In recent years support for the Republican Party has spread from support for presidential candidates to support for state and local candidates. The Republican Party's growth is due partially to Republicans moving into the region, but the rise has been not just in the most rapidly growing states. Other Southern states have elected Republican governors, representatives, and senators.

While migrants have not been completely responsible for the return to a two-party system in the South, they certainly have played a part. Migrant Republicans have maintained their views in the face of widespread Democratic loyalties (Beck, 1977; Gatlin, 1975). The groups from which these migrants come, middle and upper classes, are active politically. Migrant Republicans have standard Republican views concerning economic (e.g., spending for space exploration) and business (e.g., anti-union) issues. The Republican Party's rise depends upon migrants stressing these Republican views and their similarities to natives' views while ignoring their slightly more liberal views on social issues such as race. ${ }^{6}$ Politically astute migrants and natives for whom the Republican 
ideas hold an appeal are the basis for the rise of a real two-party system in the South.

The views of Republicans and Democrats, migrants and natives do not differ on all issues. The views on expenditures to improve conditions of blacks are not different enough for this variable to discriminate between Republicans and Democrats. This finding could be influenced by the inclusion of "leaning" Independents as members of a party. Most of these Independents who were included as Democrats are probably white, thus affecting the racial composition of the Democratic Party and, presumably, its racial views.

Another area on which there is little difference in views is on issues concerning foreign policy and the military. Although there are some differences between the parties on these questions of national concern, native Southerners do not differ from in-migrants. The South, with its large number of military institutions, will probably continue to express support for the military.

Views concerning expenditures for improving and protecting the environment also do not differ significantly. The South is an area with vast natural resources with an environment and climate which has attracted many people. Less than 12 percent of any of the four groups feels that too much is being spent on protecting the environment, ranging from 6.3 percent for migrant Democrats to 11.1 percent for migrant Republicans who again have the extreme view. All groups who live in the South value their unique environment and want to protect it.

Individuals have been aggregated into four groups and compared for this analysis: Southern members of each party (including Independents leaning toward the Party) with migrants from other regions belonging to each party (again including leaning Independents). No conclusions can be drawn about any one individual, but also no conclusions can be drawn about any particular area of the South. This analysis is concerned with the Census South and how migration is affecting it. The South is a diverse region. This diversity exists for Southern politics and for Southern migration patterns. Migrants move to areas where there are others like them, e.g., their friends or families. Migrants concentrate in areas where they perceive others like them live. For example, migrants to South Florida are different from migrants to the panhandle of Florida, and each group is more similar to the natives in that area of the state than in the other area (Gatlin, 1975). More detailed analysis of subregions would document more differences. Migrants to the South in aggregate are different from the native residents, and inherent in these differences is the potential for Southern change.

\section{FOOTNOTES}

${ }^{1}$ The South is defined as the census South, i.e., the eleven states of the Confederacy (Alabama, Arkansas, Florida, Georgia, Louisiana, Mississippi, North Carolina, South Carolina, Tennessee, Texas, and Virginia) and Delaware, Kentucky, Maryland, Oklahoma, West Virginia, and the District of Columbia. This definition is very encompassing. Impacts of migration found for this broad region would probably be more significant if a smaller, more homogeneous region was considered. Data limitations make other considerations impractical.

${ }^{2}$ Residence at age 16 is the only GSS question from which information about migration can be obtained. This measure provides an indication of the location where an individual was socialized. Migration within the South, of course, is not considered since the concern is with the efect of interregional migration.

${ }^{3}$ While these percentages of migrants who consider themselves Republicans and Democrats are related to the higher socioeconomic standing of migrants, these SES differentials are not responsible completely for this finding. In analysis not reported here, it was found that at four different educaitonal levels (less than high school graduate, high school graduate, some college, at least college graduate) the percentage of Republicans in the migrant population is higher than that found among natives. (The percentage is lower at lower levels of educational attainment.) Even among black migrants there are more Republicans than there are among natives, but the reliability of this finding is questionable because of the small number of blacks in the sample, especially black migrants, and because blacks, both natives and migrants, are overwhelmingly Democratic.

"This idea was suggested by an anonymous reviewer.

5Spending to insure the nation's health has a different impact on blacks and whites largely due to the disproportionate share of blacks in the lower class.

${ }^{6}$ Ronald Reagan's Southern strategy reflects this rationale particularly if his use of the term "states' rights" is viewed as reflecting a conservative view on the racial issue.

\section{REFERENCES}

Bartley, Numan V. and Hugh D. Graham

1975 Southern Politics and the Second Reconstruction. Baltimore: Johns Hopkins University Press.

Bass, Jack and Walter DeVries

1976 The Transformation of Southern Politics. New York: Basic Books.

Beck, Paul Allen

1977 "Partisan dealignment in the postwar South." American Political Science Review 71:477-496.

Biggar, Jeanne C.

1979 "The sunning of America: Migration to the sunbelt." Population Bulletin 34:1. Washington, D.C.: Population Reference Bureau.

Black, Merle

1978 "Racial composition of congressional districts and support for federal voting rights in the American South." Social Science Quarterly 59:435-450. 
Black, Merle, David M. Kovenock, and William C. Reynolds 1974 Political Attitudes in the Nation and the States. Chapel Hill: Institute for Research in Social Science.

Campbell, Angus, Philip E. Converse, Warren E. Miller, and Donald E. Stokes

1960 The American Voter. New York: Wiley.

Campbell, Bruce A.

1977 a "Politics of change in the partisan loyalties of native Southerners: 1952-1972." Journal of Politics 39:730-761.

1977b "Change in Southern electorate." American Journal of Political Science 27:37-64.

Carmines, Edward G. and James A. Stimson

1980 "Two faces of Issue Voting." American Political Science Review 74:78-91.

Cebula, Richard J.

1979 The Determinants of Human Migration. Lexington, Massachusetts: Lexington Books.

Davis, James A.

1978 General Social Surveys, 1972-1978: Cumulative codebook. Chicago: National Opinion Research Center. MRDF Distributor: Roper Public Opinion Research Center, Yale University, New Haven.

Freedman, Ronald and Deborah Freedman

1956 "Fram-reared elements in the nonfarm population." Rural Sociology 21:50-61.

Gatlin, Douglas S.

1973 "Florida." Pp. 329-374 in David M. Kovenock, James Prothro, and Associates (eds.), Explaining the Vote: Part II: Presidential Choices in Individual States. Chapel Hill: Institute for Research in Social Science.

1975 "Party identification, status, and race in the South: 1952-1972." Public Opinion Quarterly 39:39-51.

Jitodai, Ted T.

1964 "Migrant Status and Church Attendance." Social Forces 43:241-248.

Kessel, John H.

1972 "Comment: The issues in issue voting." American Political Science Review 66:459-465.

Key, V. O., Jr.

1949 Southern Politics. New York: Knopf.

Knoke, David

1976 Change and Continuity in American Politics the Social Bases of Political Parties. Baltimore: Johns Hopkins University Press.
Miller, Warren E. and Teresa E. Levitin

1976 Leadership and Change: The New Politics and the American Electorate. Cambridge: Winthrop.

Nie, Norman and Kristi Andersen

1974 "Mass belief systems revisited: Political change and attitude structure." Journal of Politics 36:540591.

Nie, Norman, C. Hadlai Hull, Jean G. Jenkins, Karin Steinbrenner, and Dale H. Bent

1975 Statistical Package for the Social Sciences. New York: McGraw-Hill.

Pomper, Gerald M.

1972 "From confusion to clarity: Issues and American voters, 1956-1968." American Political Science Review 66:415-428.

1975 Voters' Choice Varieties of American Electoral Behavior. New York: Dodd, Mead.

Reed, John Shelton

1972 The Enduring South. Chapel Hill: University of North Carolina Press.

Rieger, J. and J. Beegle

1974 "The integration of rural migrants in new settings." Rural Sociology 39:42-54.

Ritchey, P. Neal

1976 "Explanations of migration." Annual Review of Sociology 2:363-404.

Sharp, Harry

1955 "Migration and voting behavior in a metropolitan community." Public Opinion Quarterly 19:206209.

Strong, Donald

1977 Issue Voting and Party Realignment. University, Alabama: University of Alabama Press.

Sundquist, James L.

1973 Dynamics of the Party System. Washington, D.C.: Brookings Institution.

Wolfinger, Raymond E. and Robert B. Arseneau

1978 "Partisan change in the South, 1952-1976." Pp. 179-210 in Louis Maisel and Joseph Cooper (eds.), Political Parties: Development and Decay. Beverly Hills, California: Sage.

Wolfinger, Raymond E. and Steven J. Rosenstone 1980 Who Votes? New Haven: Yale University Press.

Zimmer, Basil G.

1955 "Participation of migrants in urban structures." American Sociological Review 20:218-224. 


\section{Appendix I}

GSS Item Used ${ }^{a}$

"We are faced with many problems in this country, none of which can be solved easily or inexpensively. I'm going to name some of these problems, and for each one I'd like you to tell me whether you think we're spending too much money on it, too little money, or about the right amount."

Space Exploration Program (NATSPAC)

Improving and Protecting the Nation's Health (NATHEAL)

Improving and Protecting the Environment (NATENVIR)

Solving the Problems of Big Cities (NATCITY)

Halting the Rising Crime Rate (NATCRIME)

Dealing with Drug Addiction (NATDRUG)

Improving the Nation's Educational System (NATEDUC)

Improving the Conditions of Blacks (NATRACE)

The Military, Armaments and Defense (NATARMS)

aStandard GSS mnenomic is given in parentheses following the item.
Foreign Aid (NATAID)

Welfare (NATFARE)

"I am going to name some institutions in this country. As far as the people running these institutions are concerned, would you say you have a great deal of confidence, only some confidence or hardly any confidence at all in them?"

Organized Religion (CONCLERG)

Education (CONEDUC)

Organized Labor (CONLABOR)

Press (CONPRESS)

U.S. Supreme Court (CONJUDGE)

Scientific Community (CONSCI)

Congress (CONLEGIS)

Military (CONARMY)

"In general, do you favor or oppose the busing of (Negro/Black) and white school children from one district to another?" (BUSING)

"Please tell me whether or not you think it should be possible for a pregnant women to obtain a legal abortion if there is a strong chance of serious defect in the baby?" (ABDEFECT)

"Do you favor or oppose the death penalty for persons convicted of murder?" (CAPPUN) 